\title{
A LAKÓTELEPEK HELYZETE NÉMETORSZÁG ÉS MAGYARORSZÁG LAKÁSPIACÁN
}

\author{
(Situation of Housing Estates in the Housing Markets \\ of Germany and Hungary)
}

\section{EGEDY TAMÁS}

\section{Bevezetés}

Nem is gondolnánk, hogy Európa keleti és nyugati felének lakótelepei között legalábbis építészeti szempontból - sokkal több a hasonlóság, mint a különbség. Természetesen ez nem a véletlen müve, hiszen e lakótelepek eredete közös, s felépitésük is hasonló okokból következett be. Elterjedésükhöz ugyanis mind nyugaton, mind keleten elsősorban a lakáshiány megjelenése vezetett, melyet lehetőség szerint rövid távon kezelni kellett. Ez nem valósulhatott volna meg potenciálisan rendelkezésre álló építési területek nélkül az érintett városokban, ugyanakkor szükség volt bizonyos fokú gazdasági és technikai fejlettségre is ahhoz, hogy ezeket a lakásokat és infrastruktúrát térben és időben ennyire koncentráltan felépíthessék (Rietdorf 1997). Ebben a tekintetben sem voltak lényeges eltérések a két országcsoport között. A nyugati és a volt szocialista országok lakótelepeinek különbségei elsősorban méretükben, felépitésük utáni továbbfejlődésükben, lakáspiacon játszott szerepükben és a lakosság összetételében keresendők.

E kérdéskör vizsgálatát különösen érdekessé teszi Németország és Magyarország lakótelepi helyzetének rövid összehasonlítása ${ }^{1}$. Egyrészt a rendszerváltozás óta az egymástól sokban különbözö kelet- és nyugatnémet lakótelepek ma már egy és ugyanazon ország határain belül találhatók meg, másrészt a magyar lakótelepek helyzetének bemutatása rávilágíthat arra, hogy a volt keleti blokkon belül a hasonlóságok ellenére a lakótelepek között jelentős különbségek is voltak.

\section{Regionális különbségek a lakótelepek méretében és területi eloszlásában}

A Német Szövetségi Köztársaságban a 2500 lakásosnál nagyobb lakótelepek száma jelenleg meghaladja a kétszázötvenet, az itt található lakásoké pedig az 1,6 milliót. Megoszlásuk a nyugati és keleti tartományok között azonban jelentös eltéréseket mutat (1. táblázat). 
Egedy Tamás : A lakótelepek helyzete Németország és Magyarország lakáspiacán

Tér és Társadalom 14. évf. 2000/2-3. 147-157. p.

148 Egedy Tamás

TÉT XIV. évf. 2000 -2-3

\section{TÁBLÁZAT}

A nyugati és keleti tartományok lakótelepeinek néhány összehasonlitó adata (Some Comparative Data of the Housing Estates in West and East Germany)

\begin{tabular}{ccccccc}
\hline \multirow{2}{*}{$\begin{array}{c}\text { lakótelep } \\
\text { nagysága }\end{array}$} & \multicolumn{3}{c}{ Nyugatnémet lakótelepek } & \multicolumn{3}{c}{ Keletnémet lakótelepek } \\
\cline { 2 - 7 } & $\begin{array}{c}\text { lakótelepek } \\
\text { száma }(\mathrm{db})\end{array}$ & $\begin{array}{c}\text { lakások } \\
\text { száma } \\
(\mathrm{db})\end{array}$ & $\begin{array}{c}\text { lakónépes- } \\
\text { ség ará- } \\
\text { nya* }(\%)\end{array}$ & $\begin{array}{c}\text { lakótele- } \\
\text { pek száma } \\
(\mathrm{db})\end{array}$ & $\begin{array}{c}\text { lakások } \\
\text { száma } \\
(\mathrm{db})\end{array}$ & $\begin{array}{c}\text { lakónépes- } \\
\text { ség aránya* } \\
(\%)\end{array}$ \\
\hline 10000 lakás $<$ & 9 & 122900 & 0,4 & 28 & 611600 & 12 \\
5000 lakás $<$ & 25 & 235900 & 0,8 & 71 & 903400 & 18 \\
2500 lakás $<$ & 110 & 516900 & 1,7 & 156 & 1198700 & 23 \\
\hline
\end{tabular}

Forrás: Bundesforschungsanstalt für Landeskunde und Raumordnung 1997; * FuhrichMannert 1994.

$\mathrm{Az}$ 1000-2500 lakásos telepeket is figyelembe véve az országban valamivel több, mint 2,3 millió lakás található lakótelepeken, ami a lakásállomány körülbelül 7\%-át teszi ki. E lakások nagyobb része a keleti tartományokban található, ahol a lakásállomány $29 \%$-át teszi ki, míg a nyugati tartományok esetében arányuk mindössze 3\%.

A lakásszámokat megvizsgálva jelentös méretbeli eltéréseket fedezhetünk fel a két országrész lakótelepei között. Míg nyugaton a kis- és közepes lakótelepek vannak túlsúlyban, a keleti tartományokban a 10000 lakásosnál nagyobb, igazi lakótelepmonstrumok is megtalálhatók, szerepük a lakásállományt tekintve jelentős (2. táblázat). $\mathrm{E}$ telepek közül mindössze kilenc található a régi tartományokban, $\mathrm{s}$ ellentétben az ország keleti részével - ahol minden nyolcadik -, itt csak minden kétszázötvenedik ember éli életét óriás-lakótelepeken.

\section{TÁBLÁZAT}

Németország legnagyobb lakótelepei a nyugati és keleti tartományokban (The Largest Housing Estates in West and East Germany)

\begin{tabular}{|c|c|c|c|c|c|}
\hline \multicolumn{3}{|c|}{ Nyugat-Németország } & \multicolumn{3}{|c|}{ Kelet-Németország } \\
\hline Város & Lakótelep & $\begin{array}{c}\text { Lakások } \\
\text { száma }\end{array}$ & Város & Lakótelep & $\begin{array}{c}\text { Lakások } \\
\text { száma }\end{array}$ \\
\hline München & Neu-Perlach & 20100 & Kelet-Berlin & Marzahn & 58200 \\
\hline Nyugat-Berlin & Gropiusstadt & 18600 & Kelet-Berlin & Hellersdorf & 42200 \\
\hline Nyugat-Berlin & $\begin{array}{l}\text { Märkisches } \\
\text { Viertel }\end{array}$ & 16900 & Halle & Neustadt & 40600 \\
\hline Nürnberg & Langwasser & 13000 & Rostock & Nord-West & 39400 \\
\hline Berlin & $\begin{array}{l}\text { Falkenhagener } \\
\text { Feld }\end{array}$ & 11600 & Leipzig & Grünau & 38500 \\
\hline
\end{tabular}

Forrás: Fuhrich-Mannert 1994.

További számottevő különbségek fedezhetök fel a lakótelepek területi elhelyezkedésében és megoszlásában is (1.ábra). A német lakótelepek mintegy fele mindössze öt keleti tartományban található. Kiemelhetö közülük Szászország, 554000 lakótelepi lakással, illetve Kelet-Berlin, ahol a lakásállomány közel 46\%-a található lakótelepeken. A régi tartományokban lakótelepekkel szinte kizárólag csak a jelentősebb népességkoncentrációjú területeken, nagyvárosokban találkozhatunk, ezeken belül is térbelileg erősen koncentrálódva. Ezzel szemben a keleti részen a lakótelepek eloszlása sokkal egyenletesebb, megtalálhatók a kevésbé sürün lakott kis- és középvárosokban, sőt falusi régiókban is. 


\section{ABRA}

Németország 2500 lakásosnál nagyobb lakótelepei (Housing Estates in Germany with more then 2500 Inhabitants)

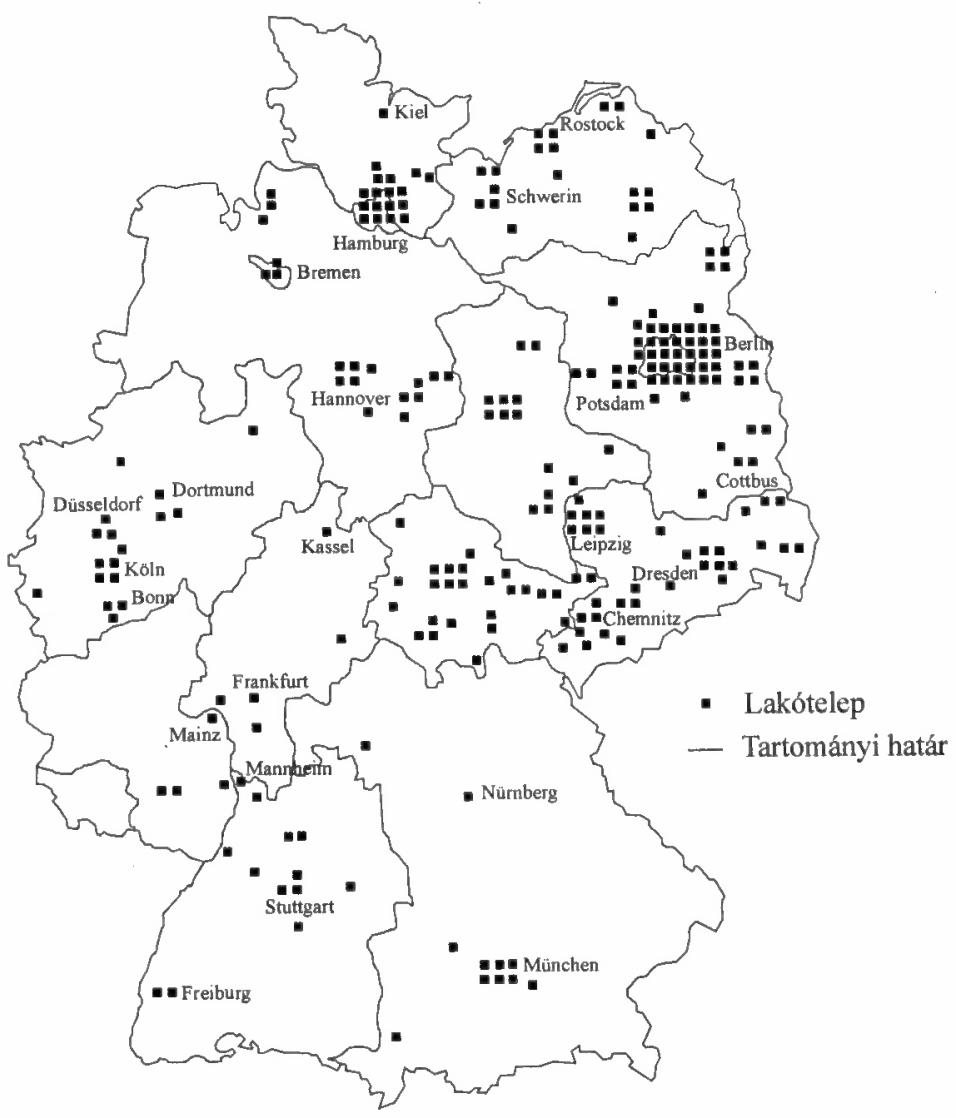

Forrás: Dokumentation der Bundesforschungsanstalt far Landeskunde und Raumordnung, 1997. 
Míg Németországban a lakótelepek elöfordulásában és méretében regionális szinten is jelentös különbségeket fedezhetünk fel, addig Magyarországon ez kevésbé jellemző. Itt elsősorban a településkategóriák szintjén jelentkeznek szembetünő eltérések: a nagyobb lakótelepeket Budapesten, a megyeszékhelyeken és az úgynevezett szocialista városokban találjuk (2.ábra).

\section{2. ÁBRA}

A 2500 lakásosnál nagyobb lakótelepek Magyarországon

(Housing Estates in Hungary with more then 2500 Inhabitants)

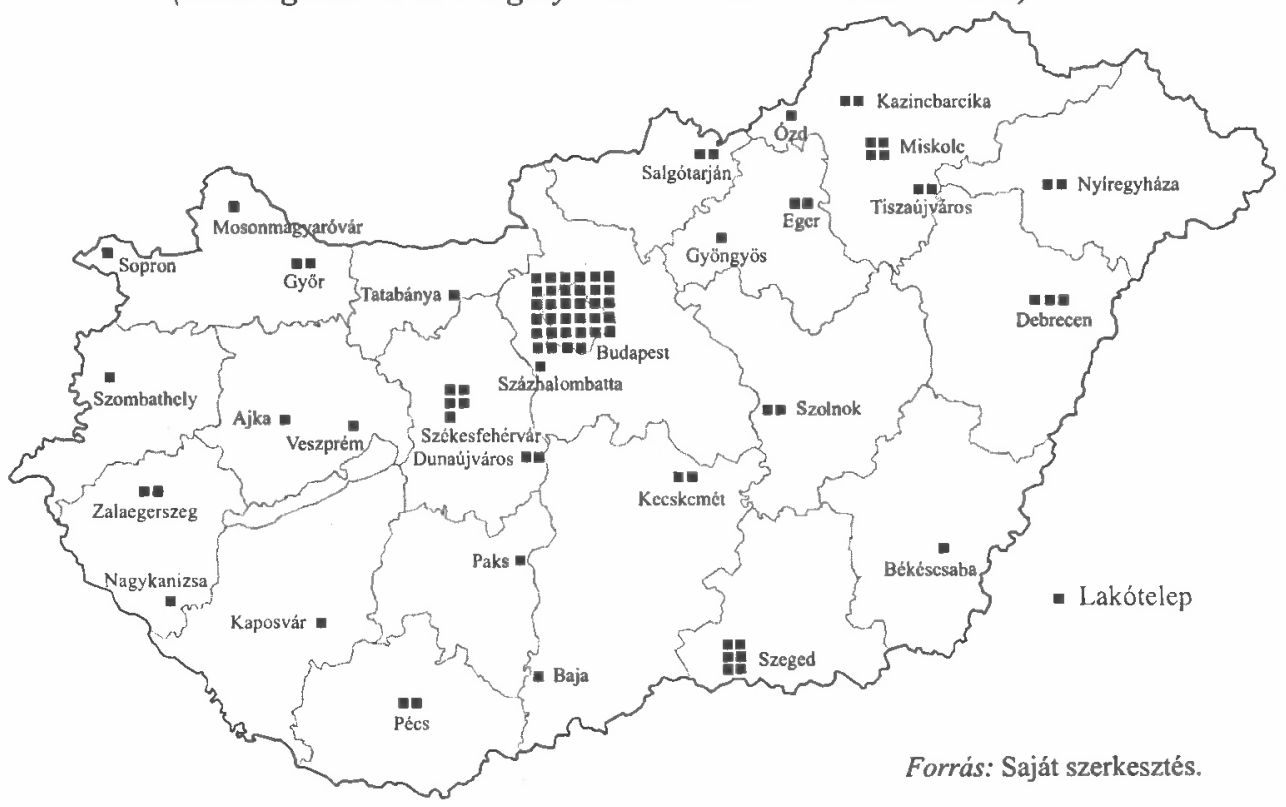

Hazánkban az 1000 lakásosnál nagyobb lakótelepek száma 173. Habár ez a magyar lakótelepeknek alig harmada, ezeken a telepeken koncentrálódik a lakásállomány $76,7 \%$-a, s hasonló arányban részesednek a lakótelepi népességböl is. $\mathrm{Az}$ 1000 lakásosnál nagyobb lakótelepek lakásszámok szerinti megoszlását vizsgálva megállapíthatjuk, hogy Magyarországon a volt szocialista országokhoz viszonyítva kevés, mindössze kilenc 10000 lakásosnál nagyobb lakótelep-óriás található (3. táblázat). Ezek az óriás-lakótelepek egyértelmúen a fóvárosra koncentrálódnak, hiszen Budapesten kívül csak Miskolcon és Pécsen fordul elö egy-egy ilyen lakótelepmonstrum. Amennyiben a méretskála másik oldalát vesszük szemügyre, megállapíthatjuk, hogy az 1000 lakásosnál kisebb lakótelepek mind számukat, mind lakásállományukat és az itt élő népesség arányát tekintve a magyar lakótelepi állomány legfontosabb kategóriája. A falvak kivételével gyakorlatilag alig akad város, amelyben legalább néhány tízlakásos lakóteleppel ne találkoznánk. Többek között éppen ez teszi rendkívül nehézzé összeírásukat és áttekintésüket. Azt azonban nyu- 
Egedy Tamás : A lakótelepek helyzete Németország és Magyarország lakáspiacán

Tér és Társadalom 14. évf. 2000/2-3. 147-157. p.

TÉT XIV. évf. 2000 -2-3

A lakótelepek helyzete...

151

godtan állíthatjuk, hogy felmérésünk eredményeit összegezve Magyarországot méltán nevezhetnénk a kislakótelepek országának.

\section{TÁBLÁZAT}

A magyar lakótelepek megoszlása nagyság és lakónépesség szerint (Distribution of Housing Estates in Hungary by Dimension and Population)

\begin{tabular}{cccccc}
\hline $\begin{array}{c}\text { Lakótelep mérete } \\
(\text { lakásszám) }\end{array}$ & $\begin{array}{c}\text { Lakótelepek } \\
\text { száma }(\mathrm{db})\end{array}$ & $\begin{array}{c}\text { Lakások } \\
\text { száma }(\mathrm{db})\end{array}$ & $\begin{array}{c}\text { Lakások } \\
\text { aránya }(\%)\end{array}$ & $\begin{array}{c}\text { Lakónépes- } \\
\text { ség (fö) }\end{array}$ & $\begin{array}{c}\text { Lakónépesség } \\
\text { aránya }(\%)\end{array}$ \\
\hline $10000<$ & 9 & 121865 & 15,5 & 342880 & 15,2 \\
$7500-10000$ & 7 & 61404 & 7,8 & 164332 & 7,3 \\
$5000-7500$ & 21 & 131821 & 16,8 & 388750 & 17,2 \\
$2500-5000$ & 41 & 137851 & 17,6 & 375860 & 16,6 \\
$1000-2500$ & 95 & 149146 & 19,0 & 440622 & 19,4 \\
$1000>$ & $\sim 427^{*}$ & 183364 & 23,3 & $549654^{*}$ & 24,3 \\
Összesen & $\sim 600^{*}$ & 785451 & 100,0 & $2262098^{*}$ & 100,0 \\
\hline
\end{tabular}

* becsült, számolt adat

Forrás: Saját felmérés.

\section{TÁBLÁZZAT}

Magyarország legnagyobb lakótelepei a fóvárosban és vidéken (Hungarian Housing Estates in the Capital and in Other Parts of the Country)

\begin{tabular}{lccc}
\hline \multicolumn{1}{c}{ Város } & Lakótelep & Lakásállomány & Lakónépesség \\
\hline Budapest & Újpest városközpont (I-II. ütem) & 16832 & 46846 \\
Budapest & Újpalotai ltp. & 15886 & 45669 \\
Budapest & Óbuda városközpont & 13736 & 35950 \\
Budapest & Békásmegyeri ltp. & 13394 & 40581 \\
Budapest & Füredi úti ltp. & 12233 & 30230 \\
\hline Pécs & Kertváros & 15856 & 44861 \\
Miskolc & Avas & 11498 & 34695 \\
Pécs & Uránváros & 9651 & 22345 \\
Tatabánya & Újváros & 8862 & 21275 \\
Kecskemét & Széchenyi város ltp. & 8673 & 35000 \\
\hline
\end{tabular}

Forrás: Saját felmérés.

Magyarországon a legtöbb és legnagyobb lakóteleppel tehát a fövárosban találkozhatunk (4. táblázat). A tipizált, azonos technológiával történỏ tömeges lakásépítés Budapesten a háborús károk és erősödő bevándorlás következtében fellépỏ lakáshiány miatt röviddel a II. világháború után elötérbe került. Ebből kifolyólag a hatvanas években épuilt lakótelepi lakások aránya a többi településtípushoz viszonyítva a fővárosban a legmagasabb (7\%). Az 1970-es években a paneles technológia erőteljesebb térhódításával különösen a fővárosban, de a vidéki nagyvárosokban is gomba módra szaporodtak a lakótelepek. Ez nagyban kihatott a lakásállomány jelenlegi összetételének alakulására is: a lakótelepi lakások aránya országos szinten megközelíti a $20 \%$-ot, Budapesten meghaladja a 33\%-ot, míg a megyeszékhelyek esetében még ennél is magasabb értékeket találunk.

A lakótelepi lakások aránya Magyarországon a különbözỏ régiókban is mutat eltéréseket: Budapesten, Nyugat-Magyarországon és a Közép-Dunántúlon a legmaga- 
sabb, a két alföldi régióban a legalacsonyabb. A Közép-Dunántúlon (Veszprém, Tatabánya, Székesfehérvár) a lakótelepi lakások aránya 59\%, ez az arány az Északmagyarországi régió megyeszékhelyein (Eger, Salgótarján, Miskolc) is magas, értéke eléri a 48\%-ot. Ugyanakkor az Alföld északi régiójának megyeszékhelyein (Debrecen, Nyíregyháza, Szolnok) csak minden harmadik lakás lakótelepi. Vannak emellett kisvárosok, amelyekben a lakótelepi építkezés volt a meghatározó. Elsősorban azok a települések sorolhatók ide, amelyek az ötvenes években az erőszakos iparosítás következtében rendkívül gyorsan növekedtek, és ahol már az 1980-as népszámláláskor is nagyon magas volt a lakótelepi lakások aránya (Dunaújváros 90,5\%, Komló 65,7\%, Ózd 35,1\%, Várpalota 23,4\%) (Lakatos 1998).

A német és magyar lakótelepek területi megoszlásában és méretében a következő alapvető különbségeket fedezhetjük fel:

- A németországi lakótelepek a nyugati és keleti tartományok között mind számukat, mind méretüket tekintve rendkívül aránytalanul oszlanak meg, ami elsősorban a 40 évig fennálló különbözö politikai rendszerek lakáspolitikájára vezethetö vissza. Magyarországon hasonló mértékủ regionális különbségek nem fedezhetök fel.

- Németország nyugati és keleti tartományait különválasztva a lakótelepek regionális megoszlását tekintve Magyarország inkább a nyugati országrészhez hasonlítható.

- A település-kategóriánkénti megoszlást megvizsgálva ugyanis megállapíthatjuk, hogy mindkét országban elsősorban a fővárosra illetve a nagyobb városokra koncentrálódnak a lakótelepek. Magyarországra ugyanakkor kevésbé jellemző a nagyobb lakótelepek elöfordulása kisvárosokban és falusias régiókban.

- A legnagyobb magyar lakótelepek méretének összevetése a németekével is feltủnő hasonlóságot mutat a régi tartományokkal, illetve az új tartományok lakótelep-monstrumaihoz hasonlók Magyarországon nem találhatók. A lakótelepek átlagos lakásszáma is lényegesen elmarad a keleti tartományokétól.

\section{Mások-e a német és a magyar lakótelepek?}

Az első kérdés, ami e témakör tárgyalásánál felvetödik, hogy tulajdonképpen mit is tekintenek lakótelepnek az egyes országokban. Németországban - mint tapasztalatai mutatják - e meghatározás sokkal jobban kidolgozott, ami talán az intenzívebb lakótelep-kutatásokra is visszavezethetö. E szerint olyan lakónegyedeket tekinthetünk lakótelepnek, amelyek a II. világháború után, túlnyomórészt az 1960-as és 1970-es években a szocialista lakókomplexum (Sozialistisches Wohnkomplex) egységes koncepciója szerint a komplex lakásépítési program keretében épülttek fel, homogén jellegüknél és több- vagy sokemeletes épületeiknél fogva környezetüktöl egyértelmủen lehatárolhatók, rendszerint a város szélén fekszenek (kisebb méretben azonban a belvárosban is elöfordulhatnak utólagos beépítés következtében), túlnyomórészt bérlakásokból állnak, s lakásállományuk meghaladja a 2500-at. 
Egedy Tamás : A lakótelepek helyzete Németország és Magyarország lakáspiacán

Tér és Társadalom 14. évf. 2000/2-3. 147-157. p.

Ezzel szemben Magyarországon a hivatalos statisztikai definíció ennél lényegesen egyszerübb, s ennek megfelelöen sokkal több kérdést is felvet, illetve megválaszolatlanul hagy. A lakótelep - a magyar lakótelepek 1980-as népszámlálás keretében elvégzett első és mindeddig utolsó teljes körủ felmérése szerint - a település közigazgatási területén elkülönülö - többnyire forgalmi utakkal határolt - településrész, amelyben összefüggő egységet alkotó lakóházcsoport van, és amelyhez általában magas és mélyépítésủ létesítmények kapcsolódnak. A lakótelepeknek ugyanakkor legalább egy számlálókörzetet kellett tartalmazniuk és önálló névvel kellett rendelkezniük. Az 1996-os mikrocenzus meghatározása szerint a lakótelep az utóbbi évtizedekben többnyire házgyári technológiával épített középmagas és magas lakóházak, házsorok együttese.

Eltérố módon közelítik meg tehát a lakótelep kérdéskörét a német és a magyar szakemberek. A német meghatározás mindenképpen gyakorlatorientáltabbnak tekinthető, míg a magyar további bővítést és pontosítást érdemel. Az összehasonlíthatóság érdekében a kutatásunk során a kidolgozottabb német definíciót alkalmaztuk. Ez azonban azonnal rávilágított a két ország lakótelepeinek egyik fontos különbségére: a német - elsősorban keletnémet - lakótelepek átlagos mérete lényegesen meghaladja a magyarokét. Az 1980-as népszámlálás szerint a lakótelepek átlagos lakásszáma Magyarországon 1270 lakás (Budapesten 1950 lakás, egyéb városokban 1069 lakás), ami az elmúlt két évtizedben biztosan nem emelkedett tovább. Sok magyar lakótelepen tehát a lakásállomány nem haladja meg a 2500-at, bár a lakótelepi lakások az adott település lakásállományában jelentös arányt képviselhetnek. Példaként említhetö Komló, ahol az általunk alkalmazott német definíció szerint lakótelep nem található, a lakótelepi lakások aránya a városban mégis meghaladja a $60 \%$-ot.

A német és magyar lakótelepek között a regionális különbségeken kívül a rendszerváltozás utáni privatizáció és az azóta követett eltérő lakáspolitika következtében további eltérések is felfedezhetők. Nincs lehetöségünk arra, hogy a privatizáció eltérő folyamatát és ennek következményeit részletesen bemutassuk. Csak utalni szeretnénk rá, hogy alapvetó különbség mutatkozik a két ország privatizációs technikáját tekintve többek között abban, hogy a magyar lakótelepeken és általában a magyar lakáspiacon ismeretlenek a társasháztulajdonos és a Zwischenerwerber ${ }^{2}$ kategóriák. A lakástulajdonosi formákat megvizsgálva alapvetö különbségek fedezhetök fel Németország, illetve általában a nyugati országok és Magyarország között. Magyarországon a lakott lakásoknak alapvetỏen két fó formája létezik: a tulajdonos által lakott lakások (magántulajdonú társasházakban, szövetkezeti lakásokban, családi házakban) és a helyi önkormányzatoktól bérelt lakások. Nyugaton a fö lakásmód ezzel szemben a magántulajdonban levő lakások bérlete, az önkormányzat kezében levő lakások pedig sokkal inkább szociális lakásként funkcionálnak. Ez persze nem jelenti azt, hogy Magyarországon nem létezik a magánbérlet, hiszen egyre többen adják bérbe második lakásukat, bár ez a piacon egyelöre elenyésző arányt képvisel (Farkas-Szabó 1994a; 1994b). Az ön- 
kormányzati lakásokat Magyarországon is egyre inkább szociális lakásként kezelik, nagy probléma viszont a szociális lakáshelyzet romlása a rendszerváltozás után.

A magyar lakáspiacot a rendszerváltozás után a német viszonyokkal összehasonlítva egyrészt erős polarizáció, másrészt rendkívül alacsony lakásmobilitás jellemzi. A polarizáció elsősorban arra vezethető vissza, hogy a társadalmon belüli jövedelmi különbségek jelentősen megnöttek. Ennek a lakótelepeket tekintve két következménye van: egyrészt folyamatosan kiszorulnak a jobb lakótelepekröl a szegényebb rétegek, vagy megindul a tehetősebbek elköltözése a rosszabb lakónegyedböl. Az alacsony lakásmobilitás már-már a magyar lakáspiac tradicionális jellemzőjének mondható. Az életcélként szereplö lakástól az emberek nem szívesen válnak meg, arra még mindig úgy tekintenek, mint az egyik legbiztosabb beruházásra.

Összességében megállapítható, hogy a lakótelepek Magyarországon mindenképpen a privatizáció veszteseinek tekinthetök. Erre utal az a tény is, hogy a kilencvenes évek első felében a lakótelepi lakások ára a névérték emelkedése ellenére mintegy 50\%-os reálérték-veszteséget mutatott. A különböző generációjú lakótelepek piaci megítélése azonban korántsem volt egyforma. Legkedvezőbb helyzetben a nyolcvanas évek elitlakótelepei voltak, az itt található lakások ára ugyanis lépést tudott tartani az inflációval. A többi generáció esetében már egyértelmủ reálértékcsökkenésről beszélhetünk. Meglepö az ötvenes évekbeli lakótelepek viszonylag kedvező helyzete, ami többek között e telepek tradicionális építési technológiájára, emberi léptékére, kedvező fekvésére vezethetö vissza. A lakáspiaci leértékelődés különösen a hetvenes években épült lakótelepek esetében szembetűnő, jelenleg ezek küzdenek a legtöbb problémával ezen a téren (Kovács-Douglas 1996). További jelentős probléma Magyarországon, hogy a lakások privatizációjával a lakótelepeken vegyes tulajdonú épületek jöttek létre, ahol egyre nagyobb feszültségek forrásává válik a közös költségek és a lakbérek összehangolása. Sokan voltak ugyanis, akik utolsó filléreiket fordították a lakás tulajdonjogának megszerzésére, s a közös költségeket már nem tudják - és gyakran nem is akarják - fizetni. Ez jelentős konfliktusokhoz vezet egyes lakótelepek lakástulajdonosai között. A tulajdonosi formák hasonló szintủ keveredése a német lakótelepeken nem jellemzö.

A lakótelepek épített környezetében is felfedezhető néhány különbség a két ország esetében, bár az épületek hasonló elvek alapján és gyakorlatilag azonos technológiával készülttek. Mindenképpen említést érdemelnek itt a lift nélküli hatemeletes épületek Kelet-Németországban, melyekhez hasonlóval nemcsak Magyarországon nem találkozhatunk, hanem szinte egész Európában egyedülállónak számítanak. A lakóházak építésében nemzetközileg elfogadott gyakorlat volt, hogy lift nélkül legfeljebb ötszintes (azaz földszint + négy emelet) épületek építhetök. A hetvenes években a korábbi NDK-ban a pártelöírások szerint azonban jelentősen emelni kellett a lakássürüséget, ami legegyszerübben és legolcsóbban úgy volt kivitelezhető, hogy az építendő lakóházakat egy további emelettel toldották meg lift beiktatása nélkül. A lift hiánya ezekben az ötemeletes (hatszintes) épületekben jelenleg a legégetőbb problémák egyike. Bár a lift utólagos hozzáépítése a legkölt- 
ségesebb szanálási eljárások közé tartozik, mégsem véletlen, hogy nagy hangsúlyt helyeznek ezek pótlására.

Legnagyobb kuilönbségek a két ország között a lakótelepek felújításában, modernizálásában és revitalizációjában tapasztalhatók, ami nagyban meghatározza majd e telepek jövőbeli fejlődését is. Németországban már felismerték a lakótelepek fontosságát, különösen az új tartományok lakásállományában játszott szerepét és ennek megfelelően megtették az első lépéseket. 1993-ban indították el azt az állami támogatási programot, melybe 1995 végéig az új tartományok 123 városának 157 lakótelepét vették fel mintegy 832000 lakással (Bund-Länder-Förderprogramm 1996). E program keretében az állam - a tartománnyal és helyi önkormányzattal együttmủködve - anyagi támogatást nyújt az adott lakótelepek építészeti, városrendezési fejlesztéséhez, megteremtve ezáltal a lehetőséget ezen lakónegyedek modernizálásához és felzárkóztatásához. Magyarországon hasonló, átfogó jellegủ országos koncepció és fejlesztési program még nem készült, és a közeljövőben sem várható, igaz az ország anyagi lehetőségei is jóval korlátozottabbak. A fentiek ismeretében várható, hogy a magyar lakótelepi élet minősége a némethez képest viszonylagosan folyamatosan romlani fog, és a magyar lakótelepek fejlỏdési üteme is lassúbb lesz német rokonaikénál.

\section{Összefoglalás}

Mint azt elemzésünk is mutatta, a nyugati és volt szocialista országok lakótelepeinek épített, társadalmi és természeti környezetében jelentős különbségek fedezhetök fel, melyek alapvetően az eltérő társadalmi-gazdasági rendszerre vezethetők vissza. Németország esetében ez különösen érdekes szituációt eredményezett, hiszen az újraegyesítéssel e két, egymástól jelentősen különböző lakótelep-állomány ebben a tekintetben erősen kétarcúvá formálta az országot. Ugyanakkor arról is meggyőződhettünk, hogy a volt keleti blokk országaiban is voltak jelentős különbségek a lakótelepek között. Ezek az eltérések különösen a rendszerváltozás után erösödtek fel, aminek következtében ezen lakótelepek az adott országok lakáspiacán eltéró eséllyel indultak, $\mathrm{s}$ ma is eltérő pozíciót foglalnak el. A lakótelepek további fejlődése nagyban függ majd attól, hogyan, s milyen lépésekkel, s milyen formában sikerül visszaintegrálni őket a lakáspiacra.

Mára egyértelmüvé vált, hogy a lakótelepi élet a társadalom meghatározott rétegeinek igényeit elégíti ki. A nyugati országokban a lakótelepek építése már viszonylag korán, a hetvenes években visszaszorult. Ez a folyamat a keleti országokban a rendszerváltozás után gyorsult fel, s napjainkban is tart. Kérdés, hogy milyen új folyamatok indulnak meg az új évezred küszöbén, s mi lesz ezek hatása? Mi lesz a lakótelepeken lakó sok százezer emberrel? Mindenki sajnos nem költözhet zöldövezeti lakásba, kertvárosi luxusvillába, a lakótelepekkel tehát a lakáspiacon még hosszú ideig számolni kell. 


\section{Jegyzetek}

${ }^{1}$ Az összehasonlító tanulmány az OTKA támogatásával, az F029781 sz. kutatás keretében készúlt.

${ }^{2} 1990$ elött az NDK jelentős kölcsönöket vett fel állami bankjaitól a lakásépítések finanszirozásához, ez azonban nem jelentett problémát, hiszen a pénz állami kézben maradt. A két német állam egyesülése után azonban a bankok szövetségi kézbe, míg a lakásállomány önkormányzati vagy lakásszövetkezeti kézbe kerültek. A bankok visszakövetelték a lakásépítésekhez korábban felvett hiteleket, melyeket természetesen az adósok nem tudtak tơrleszteni. Az ún. Altschuldengesetz értelmében ezért a tulajdonosnak a lakásállomány $15 \%$-át privatizálnia kellett, s a befolyt összeget a banknak adósságtörlesztésként át kellett utalnia. Sok tulajdonos nem volt képes a lakásállomány $15 \%$-át eladni, mert nem talált vevöt. A lakáspiacon ekkor jelentek meg a „Zwischenerwerberek”, akik elegen đö tökével rendelkeztek a lakások felvásárlásához. Az önkormányzatok vagy lakásszővetkezetek a lakásokat (gyakran egész társasházakat és lakótömböket) ezeknek a köztes tulajdonosoknak adták el, akik a felújítási munkálatok után a lakásokat továbbértékesítették a lakáspiacon.

\section{Irodalom}

Bund-Länder-Förderprogramm - Städtebauliche Weiterentwicklung großer Neubaugebiete in den neuen Länder und im Ostteil Berlins. Ziele und erste Ergebnisse. (1996) Bonn/Berlin, Bundesministerium für Raumordnung, Bauwesen und Städtebau.

Farkas E. J.-Szabó M. (1994a) Az önkormányzati bérlakásban ébk lakásviszonyai I. - Statisztikai Szemle. 3. 197-213. o.

Farkas E. J.-Szabó M. (1994b) Az önkormányzati bérlakásban éb́k lakåsviszonyai II. - Statisztikai Szemle. 4-5. 285-297. o.

Farkas E. J.-Vajda Á.-Vita L. (1995) A budapesti lakáspiac kutatása. - Statiszzikai Szemle. 3. 242-265. o.

Fuhrich, M.-Mannert, H. (1994) Großwohnsiedlungen - Gestern, Heute, Morgen. - Informationen zur Raumentwicklung. 9. 567-585. o.

Großwohnsiedlungen. (1997) - Dokumentation der Bundesforschungsanstalt für Landeskunde und Raumordnung. Stand 1. Oktober.

Hegedüs J. (1998) A magyar lakásszektor piaci átalakulásának ellentmondásos folyamata. - InfoTársadalomtudomány. 43. 49-58. o.

Hegedüs J.-Várhegyi É. (1999) A lakásfinanszírozás válsága. - Közgazdasági Szemle. 2. 101-120. o.

Irion, I.-Sieverts, T. (1991) Neue Städte - Experimentierfeld der Moderne. Stuttgart, Deutsche VerlagsAnstalt.

Kovács Z.-Douglas M. (1996) A városépítés idözített bombája - avagy a magyar lakótelepszindróma társadalomföldrajzi megközelítésben. - Földrajzi Értesitö. 1-2. 101-117. o.

Lakatos M. (1998) A lakótelepi lakások és lakbik. Mikrocenzus 1996. Budapest, Központi Statisztikai Hivatal.

Rietdorf, W. (1997) Zur Situation der Großwohnsiedlungen ehemals sozialistischer Länder und zur Entwicklung der Großwohnsielungen im östlichen Deutschland. Großwohnsiedlungen in europäischen Städten. - Müller, E. (Hrsg.), Beiträge zur regionalen Geographie. 45. Leipzig, Selbstverlag Institut für Länderkunde. 7-16. o.

\section{SITUATION OF HOUSING ESTATES IN THE HOUSING MARKETS OF GERMANY AND HUNGARY}

\section{TAMÁS EGEDY}

Because of the destruction of World War II, and the declining number of house construction in the 30's and the 40's in the whole of Europe, there was a housing shortage. The situation after World War II resulted in the appearance of large housing estates in Europe. Housing estates cannot be considered as product of the socialist system since they can also be found in Western Europe though their significance and role differ from that of the 
former socialist countries. Housing estates on the housing market of Western countries are important, nevertheless they represent only a low proportion of the whole dwelling stock. The problems of housing estates in East-Central European countries are more serious, since the number of dwellings in housing estates and people living there goes far beyond the WestEuropean scales. Through the comparison of the German and Hungarian housing estates this paper presents the main differeneces between the Western and East-European types of highrise housing estates, their role, present situation and future perspectives on the housing market. Up to now, it became a fact, that the estate-life satisfies the claim of a determined class of the society. The question is what processes will start at the door of the new millennium; and what will be the results of these processes? What will be the destiny of those hundreds of thousands of people, living in the housing estates? 